\title{
PERLINDUNGAN HUKUM TERHADAP HAK PATEN DALAM SEBUAH PRODUK
}

\author{
DEVI RISTA \\ NPM 155100019 \\ Fakultas Komputer, KDV 4487571591 \\ devirista.student@umitra.ac.id
}

\begin{abstract}
Paten adalah hak eksklusif yang diberikan oleh negara kepada inventor atas hasil invensinya dibidang teknologi, yang untukselama waktu tertentu melaksanakan melaksanakannya. Sedangkan perlindungan hukum atas paten diperlukan bagi pemilik paten (inventor) serta pemilik lisensi paten agar dapat membuat, menjual, menginpor, menyewakan, menyerahkan, memakai dan menyediakan untuk dijual atau disewakan atau diserahkan produk/barang yang diberi paten. Namun dengan setelah kadaluwarsanya paten sehingga menjadi public domain dapat menimbulkan implikasi hukum yang berbeda-beda bagi pemilik paten (inventor), pemilik lisensi paten yang masih berlaku terhadap paten yang telah kadaluwarsa, dan masyarakat (inventor baru) yang hendak menambahkan atau menyempurnakan invensi yang telah kadaluwarsa tersebut menjadi invensi yang lebih sempurna dan nantinya dapat dipatenkan kembali. Hak paten merupakan hak eksklusif inventor atas invensi di bidang teknologi untuk selama waktu tertentu melaksanakan sendiri atau memberikan persetujuan kepada pihak lain untuk melaksanakan invensinya.

Pentingnya pendaftaran paten oleh individu maupun perusahaan. Baik suatu perusahaan yang kemudian akan berdampak pada keuntungan secara financial.

Ada 2 macam sistem pendaftaran paten dalam perlindungan hukum, yaitu sistem first to file dan Sistem first to invent. Paten merupakan objek terhadap temuan atau invensi dalam bidang teknologi yang secara praktis dapat dipergunakan dalam bidang penindustrian.
\end{abstract}

Kata Kunci : Hak Paten dan Inventor 


\section{A. INTRODUCTION}

Materi $\mathrm{Ke} 3$ membahas mengenai paten, inventor, pemegang paten, hal yang dihindari saat ajakan paten dan penjelasan penelitian dan penemuan.

a. Paten

\section{Apa itu paten?}

Paten adalah hak khusus yang diberikan Negara kepada penemu atas hasil penemuannya di bidang teknologi, untuk lama waktu tertentu melaksankan sendiri penemuannya tersebut atau memberikan persetujuannya kepada orang lain untuk melaksanakan (pasal 1 ayat 1 UU tentang paten). Atau dengan kata lain paten adalah hak eksklusif inventor atas invensi di bidang teknologi untuk selama waktu tertentu melaksanakan sendiri atau memberikan persetujuan kepada pihak lain untuk melaksanakan invensinya.

Invensi adalah ide inventor yang dituangkan ke dalam suatu kegiatan pemecahan masalah yang spesifik dibidang teknologi, dapat berupa produk atau proses atau penyempurnaan dan pengembangan produk atau proses.
Invensi dapat dipatenkan jika invensi tersebut :

1. Jika pada saat pengajuan permohonan paten invensi tersebut tidak sama dengan teknologi yang diungkapakan sebelumnya.

2. Mengandung lankah inventif. Jika invensi tersebut merupakan hal yang tidak dapat diduga sebelumnya bagi seseorang yang mempunyai keahlian tertentu di bidang teknik.

3. Dapat diterapkan dalam indusri. Jika invensi tersebut dapat diproduksi atau dapat digunakan dalam berbagai jenis industri.

\section{Berapa lama paten berlaku?}

1. Paten diberikan untuk jangka waktu selama 20 tahun sejak tanggal penerimaan permohonan Paten.

2. Paten sederhana diberikan untuk jangka waktu 10 tahun sejak tanggal penerimaan permohonan paten sederhana.

\section{b. Inventor}

Apakah yang dimaksud dengan inventor?

Inventor adalah seorang yang secara sendiri atau beberapa orang yang secara bersama-sama

melaksanakan ide Yang dituangkan ke dalam kegiatan yang 
menghasilkan invensi
(temuan). (UU RI No.14
Tahun 2001 Pasal 1 Ayat 3)

\section{c. Pemegang Paten}

Siapakah Pemegang Paten?

Pemegang paten adalah inventor sebagai pemilik paten atau pihak yang menerima hak tersebut dari pemilik paten atau pihak lain yang menerima lebih lanjut hak tersebut, yang terdaftar dalam Daftar Umum Paten.

\section{Hak dan kewajiban pemegang} paten :

1. Pemegang paten memiliki hak eksklusif untuk melaksanakan paten yang dimiliknya dan melarang orang lain yang tanpa persetujuannya :

a. Dalam hal paten produk: membuat, menjaul, mengimport, menyewa, menyerahkan, memakai, menyediakan untuk dijual atau disewakan atau diserahkan produk yang diberi paten.

b. Dalam hal paten proses : menggunakan proses produksi yang diberi paten untuk membuat barang dan tindakan lainnya sebagaimana yang dimaksud dalam huruf a.

2. Pemegang paten berhak memberikan lisensi kepada orang lain berdasarkan surat perjanjian lisensi

3. Pemegang paten berhak menggugat ganti rugi melalui pengadilan negeri setempat, kepada siapapun, yang sengaja dan tanpa hak melakukan perbuatan sebagaimana dimaksud dalam butir 1 diatas.

4. Pemegang paten berhak menuntut orang yang dengan sengaja dan tanpa hak melanggar hak pemegang paten dengan melakukan salah satu tindakan sebagaimana yang dimaksud dalam butir 1 diatas.

\section{Kewajiban pemegang paten :}

1. Pemegang paten wajib membayar biaya pemeliharaan yang disebut biaya tahunan,

2. Pemegang paten wajib melaksanakan patennya di wilayah Negara Republik Indonesia, kecuali apabila pelaksanaan paten tersebut secara ekonomi hanya layak bila dibuat dengan skala regional dan ada pengajuan permohonan tertulis dari pemegang paten dengan disertai bukti-bukti yang diberikan oleh instansi yang berwenang dan disetujui oleh Direktorat Jenderal Hak Kekayaan Intelektual (DJHKI)

\section{d. Hal yang dihindari saat ajakan paten} Apakah yang harus dihindari sebelum permintaan paten diajukan?

Yang harus dihindari sebelum permintaan paten diajukan adalah pengungkapan atau mempublikasikan secara umum hasil penelitian atau penemuan 
dalam jangka waktu lebih dari 6 (enam) bulan sebelum permintaan paten diajukan.

\section{e. Penjelasan penelitian dan} penemuan

Pengungkapan suatu haisl penelitian atau penemuan dapat terjadi dalam 3 (tiga) cara :

1. Melakukan penguraian teknik dengan tulisan yang dipublikasikan.

2. Melalui penguraian produk dan atau cara pengunaannya di depan umum

3. Melalui pameran produk, dapat berupa suatu pameran internasional d indonesia atau diluar negeri yang resmi atau diakui sebagai resmi atau berupa suatu pameran nasional di indonesia yang resmi atau diakui sebagai resmi.

\section{Ada berapa macam sistem pendaftaran paten?}

Ada 2 macam sistem pendaftaran paten dalam perlindungan hukum, yaitu sistem first to file adalah suatu sistem yang memberikan hak paten bagi mereka yang mendaftar pertama atas invensi baru sesuai dengan persyaratan. Sistem first to invent adalah suatu system yang memberikan hak paten bagi mereka yang menemukan inovasi pertama kali sesuai dengan persyaratan yang telah ditentukan.

Dalam memberikan hak paten kepada pengusul, pemerintah indonesia mengacu pada sistem First to file.

\section{B. CONCLUSION}

Hak paten merupakan hak eksklusif inventor atas invensi di bidang teknologi untuk selama waktu tertentu melaksanakan sendiri atau memberikan persetujuan kepada pihak lain untuk melaksanakan invensinya.

Pentingnya pendaftaran paten oleh individu maupun perusahaan. Baik suatu perusahaan yang kemudian akan berdampak pada keuntungan secara financial.

Ada 2 macam sistem pendaftaran paten dalam perlindungan hukum, yaitu sistem first to file dan Sistem first to invent .

Paten merupakan objek terhadap temuan atau invensi dalam bidang teknologi yang secara praktis dapat dipergunakan dalam bidang penindustrian. 
C. ACKNOWLEDGEMENT

University Of Indonesia

University Of Mitra Indonesia

Telkom University

University Of Mellbourne

Saitama University
D. REFERENCE(Based ISO 690 )

[1] A. S. Putra And O. M. Febriani, "Knowledge Management Online Application In Pdam Lampung Province," In Prosiding International Conference On Information Technology And Business (Icitb), 2018, Pp. 181-187.

[2] A. S. Putra, O. M. Febriani, And B. Bachry, "Implementasi Genetic Fuzzy System Untuk Mengidentifikasi Hasil Curian Kendaraan Bermotor Di Polda Lampung," J. Sist. Inf. Dan Manaj. Basis Data, Vol. 1, No. 1, Pp. 21-30, 2018.

[3] O. M. Febriani And A. S. Putra, "Sistem Informasi Monitoring Inventori Barang Pada Balai Riset Standardisasi Industri Bandar Lampung," J. Inform., Vol. 13, No. 1, Pp. 90-98, 2014.

[4] Putra, Arie Setya. "2018 Artikel Struktur Data, Audit Dan Jaringan Komputer." (2018).

[5] Putra, A. S. (2018, July 17). Paperplain Fundamental Create Application With Borland Delphi 7.0 University Of Mitra Indonesia. Retrieved From Osf.Io/Pbrn9. 


\section{E. REFERENCE(Based APA )}

Putra, A. S., Aryanti, D. R., \& Hartati, I. (2018, November). Metode SAW (Simple Additive Weighting) sebagai Sistem Pendukung Keputusan Guru Berprestasi (Studi Kasus: SMK Global Surya). In Prosiding Seminar Nasional Darmajaya (Vol. 1, No. 1, pp. 85-97).

Sari, D. P., Febriani, O. M., \& Putra, A. S. (2018, November). Perancangan Sistem Informasi SDM Berprestasi pada SD Global Surya. In Prosiding Seminar Nasional Darmajaya (Vol. 1, No. 1, pp. 289-294).

Putra, A. S. (2018). Paperplain: Execution Fundamental Create Application With Borland Delphi 7.0 University Of Mitra Indonesia.

Putra, A. S., Sukri, H., \& Zuhri, K. Sistem Monitoring Realtime Jaringan Irigasi Desa (JIDES) Dengan Konsep Jaringan Sensor Nirkabel. IJEIS (Indonesian Journal of Electronics and Instrumentation Systems), 8(2), 221232.

Darmawan, A., Yuliawati, D., Marcella, O., \& Firmandala, R. (2016). Sistem Absensi dan Pelaporan Berbasis Fingerprint dan SMS Gateway. EXPLORE, 7(1).

Febriani, O. M., Wahyuni, T., \& Yusuf, S. (2017). DESIGN OF WEBSITE-BASED INFORMATION SYSTEM FOR EDOCUMENT ADMINISTRASI IN THE COMMUNITY SERVICE UNIT (A Case Study at Rajabasa District). INTERNATIONAL JOURNAL OF
COMPUTERS \& TECHNOLOGY, 16(7), 7010-7020.

Febriani, O. M., \& Wahyuni, T. (2017, October). PERANCANGAN SISTEM E-DOCUMENT ADMINISTRASI LOGBOOK PENELITIAN PADA UNIT LAYANAN DI BANDAR LAMPUNG. In Prosiding Seminar Nasional Darmajaya (Vol. 1, No. 1, pp. 187-194).

Febriani, O. M., \& Permadi, A. B. (2017). Implementasi Sistem Aplikasi Data Bimbingan dan Pelanggaran Siswa pada Sekolah Menengah Atas di Lampung Tengah dengan Metode Analisis dan Desain Sistem Terdistribusi (SSAD). EXPERT, 7(1).

Febriani, O. M., \& Ambarwati, L. (2015). PERANCANGAN APLIKASI PENGOLAHAN DATA PENJUALAN UKM KELANTING KHAS TELO DESA SIDOHARJO KECAMATAN JATI AGUNG KABUPATEN LAMPUNG SELATAN. Jurnal Teknologi Informasi dan Bisnis Pengabdian Masyarakat Darmajaya, 1(1), 77-95.

Febriani, O. M. (2015). Rancang Bangun Aplikasi Ecommercemenggunakan Freewebstore pada UKM Kelanting di Desa Sidoharjo Lampung Selatan. Prosiding Sembistek 2014, 1(02), 446-458. 